\title{
Primary culture of bovine gall bladder epithelial cells
}

\author{
J N Plevris, S W Walker, D J Harrison, A Dhariwal, P C Hayes, I A D Bouchier
}

\begin{abstract}
Gall bladder epithelial cells serve numerous biological functions and abnormalities in their function are important in the pathogenesis of several gall bladder diseases. Direct studies on cell function are rare due to lack of reliable methods to culture this epithelium. This study reports a reliable and reproducible method of harvesting and culturing gall bladder epithelial cells. Normal bovine gall bladder epithelium, obtained within 20 minutes of slaughter, was rinsed with modified Hanks's balanced salt solution, the mucosa separated and incubated in trypsin - EDTA solution at $37^{\circ} \mathrm{C}$. The cells were isolated and resuspended in Dulbeco's modification of Eagles' medium containing $10 \%$ fetal calf serum and, after filtration and centrifugation, were plated under aspetic conditions. The growth rate was established by flow cytometry and the morphological characteristics of the growing cells by electron microscopy. Gall bladder epithelial cells grew successfully and visible clusters of cells were present by day two, confluency being reached at 8 to 10 days in collagen coated plates and 12 to 14 days in uncoated plates. Electron microscopy showed typical gall bladder epithelia with microvilli, tight junctions, and mucus droplets. This method proved reliable and reproducible for the culture of gall bladder epithelial cells and should allow direct studies of the biological properties of these cells in human tissue.
\end{abstract}

(Gut 1993; 34: 1612-1615)

The gall bladder epithelium has been considered for many years to be an excellent model for the study of the physiological properties of epithelial cells and in particular ion transport. More recently it has been appreciated that the mucosa significantly changes the composition of gall bladder bile by either the absorption or secretion of several constituents of bile. ${ }^{1-4}$ The gall bladder epithelium has one of the highest rates of water absorption of body tissues, which is achieved by the coupling of active sodium transport and passive water absorption. ${ }^{5}$ Chloride is actively absorbed in exchange for bicarbonate. ${ }^{6}$ Potassium and calcium move according to electrochemical gradients. ${ }^{78}$ Most of the organic components of bile, namely bile acids, lecithin, bilirubin, and cholesterol are absorbed to a limited extent by the gall bladder mucosa. ${ }^{79}$ In addition, the gall bladder epithelial cell secretes biliary proteins, ${ }^{10}$ mucin, ${ }^{11}$ and more recently it has been shown to secrete hydrogen ions. ${ }^{1213}$ As such, its role in the pathogenesis of gall stone formation is being increasingly recognised. Furthermore, study of the immunological characteristics of gall bladder and biliary epithelial cells should help elucidate the pathogenesis of biliary tree disorders.
Until recently, all studies on gall bladder epithelial cells have been restricted to using part or whole of the gall bladder. Several physiologists have used gall bladders from animal species to study ion transport and the electrical properties of the epithelium by applying either the Ussing chamber technique ${ }^{14}$ or whole organ preparation technique. ${ }^{15} 16$ More recently, other research workers used human and animal gall bladders to study aspects of epithelial cell function in relation to gall stone formation. ${ }^{217}$ Although these techniques are valuable for transport studies, they provide little information on the biological properties of the gall bladder epithelial cell itself.

Another limiting factor in studying the properties of human gall bladder epithelium has been the lack of normal tissue. This has now become more readily available with the development of liver transplantation programmes. Alternatively, many animal models have been used to overcome the lack of availability of normal human tissue. The development of a simple and reliable method of obtaining and culturing gall bladder epithelial cells from a readily available source would permit a detailed study of the biological functions of these cells and would contribute to our understanding of the pathophysiology of diseases of the biliary tree. In this paper we describe a simple, reproducible method of culturing gall bladder epithelial cells from a readily available source, the bovine gall bladder.

\section{Methods}

\section{CELL ISOLATION}

Bovine gall bladder was obtained from the local abattoir and transferred on ice to the Laboratory within 20 minutes of slaughter. The gall bladder was opened and the lumen rinsed with modified Hanks's balanced salt solution (HBSS, Sigma Chemical Co Ltd, St Louis, USA) to remove bile and debris. The mucosa was stripped from the underlying muscular layer and fat by blunt dissection. Two circular pieces $(2-3 \mathrm{~cm}$ diameter) of mucosa were used from the fundus of the gall bladder for harvesting the cells. The mucosa was left for 15 minutes in preoxygenated HBSS and then rinsed in a series of Petri dishes containing $20 \mathrm{ml} \mathrm{HBSS}$ with $5 \mathrm{ml} \mathrm{N}$-acetylcysteine $(1 \mathrm{mg} / \mathrm{ml})$ (Sigma Chemical Co Ltd) to dissolve the mucus. Each piece was then incubated for 20 minutes at $37^{\circ} \mathrm{C}$ in $20 \mathrm{ml}$ trypsin-EDTA $(0.5 \mathrm{~g}$ trypsin $1 / 250$ and $0.2 \mathrm{~g}$ EDTA $4 \mathrm{Na} / 1$, in Hanks's balanced solution, $\mathrm{Ca}^{2+}$ and $\mathrm{Mg}^{2+}$ free (Sigma Chemical Co Ltd)) sufficient to cover the tissue completely. The tissue was subsequently transferred to a second beaker with $4 \mathrm{ml}$ bovine calf serum (Sigma Chemical Co Ltd) added to inactivate the trypsin. The solution was then made up to $20 \mathrm{ml}$ 
by adding HBSS. After incubation for five minutes at room temperature to allow trypsin inactivation, the gall bladder epithelial cells were detached by gently scrapping the mucosa with the end of a glass microscope slide held at an angle of $45^{\circ}$. The separated cells were resuspended in HBSS solution and filtered sequentially through a stainless steel sieve of 0.38 $\mathrm{mm}$ (size 40 ) and $0.28 \mathrm{~mm}$ (size 50 ) pore size respectively. The above procedures were performed in a laminar flow hood using conventional sterile techniques.

The filtered solution was then centrifuged at $3 \mathrm{~g}$ for five minutes, the supernatant removed, and the cells resuspended in $10 \mathrm{ml}$ of HBSS solution. The cells were counted with a modified Neubauer haemocytometer. The percentage cell viability was checked by dye exclusion with $0.4 \%$ trypan blue under normal light microscopy.

\section{CELL CULTURE}

The final suspension was centrifuged and the cell pellet resuspended in Dulbeco's modification of Eagles' medium containing 10\% fetal calf serum and added antibiotics (50 IU/ml penicillin, $50 \mu \mathrm{g} / \mathrm{ml}$ streptomycin and $2.5 \mu \mathrm{g} / \mathrm{ml}$ amphotericin B) to a concentration of $1 \times 10^{6}$ cells $/ \mathrm{ml}$. The cells were subsequently plated under aseptic conditions in plastic multiwell plates $(15 \mathrm{~mm}$ diameter well adding $1 \mathrm{ml}$ of the above suspension to each well). Both uncoated and coated (with collagen type IV or Cytodex 3 microbeads) plates were used and the plates incubated in a standard $95 \%$ air $/ 5 \% \mathrm{CO}_{2}$ incubator at $37^{\circ} \mathrm{C}$. Round glass cover slips ( $15 \mathrm{~mm}$ diameter) were also used in some wells. The medium was routinely changed after 24 hours and thereafter every 48 hours. Reverse phase microscopy was performed regularly to monitor the progress of the cultures.

\section{MONITORING OF CELL GROWTH AND}

CHARACTERISATION OF CELLS

The cell cultures were inspected and photographed at daily intervals. DNA flow cytometry was performed on cells disrupted from the culture monolayer by EDTA treatment using standard techniques, ${ }^{18}$ to define the percentage of cells in $G_{2} / M$ phase (division), $S$ phase (DNA synthesis), and $G_{o}$ phase (resting). The cell nuclei were stained with propidium iodide and analysed by an EPICS V Flow Cytometer (Coulter, UK). The analysis of cell cycle activity was done by EASY 2 computer programme.

Transmission electron microscopy was used to analyse the morphological features of the growing cells. The cells were fixed in $48 \%$ glutaraldehyde for 24 hours, then fixed in osmium tetroxide, and stained with uranyl acetate on nickel grids using standard techniques. Grids were viewed on a Jeal 2 Electron microscope.

\section{Results}

A yield of around $5 \times 10^{6}$ cells/g tissue was obtained from the $5-10 \mathrm{~g}$ of gall bladder mucosa used. The viability of the harvested cells was in excess of $99 \%$ as assessed by the trypan blue exclusion method. With a range of culture media (MCDB-153, Eagles' medium, and Dulbeco modified Eagles' medium) satisfactory plating and growth occurred with most media. This was assessed by two independent investigators by observing (a) the cell appearance and their ability to attach to the plate in the first 24 hours and (b) the length of time the culture required to reach confluency from the same starting number of cells per well. Dulbeco's modified Eagles' medium containing $10 \%$ fetal calf serum had an advantage in both plating efficiency and growth.

Cell attachment was clearly improved in the plates coated with collagen type IV; nevertheless, satisfactory results were obtained with uncoated plastic plates and glass cover slips avoiding the cost of type IV collagen. Visible clusters of epithelial cells were present by day 2 ; the attached epithelial cells looked flattened with prominent nuclei (Fig 1A). Significant growth was present by day 6 (Fig 1B). In the coated plates (type IV collagen) confluency was reached at 8 to 10 days (Fig 1C); in the uncoated plates at 12 to 14 days. No problems with contamination
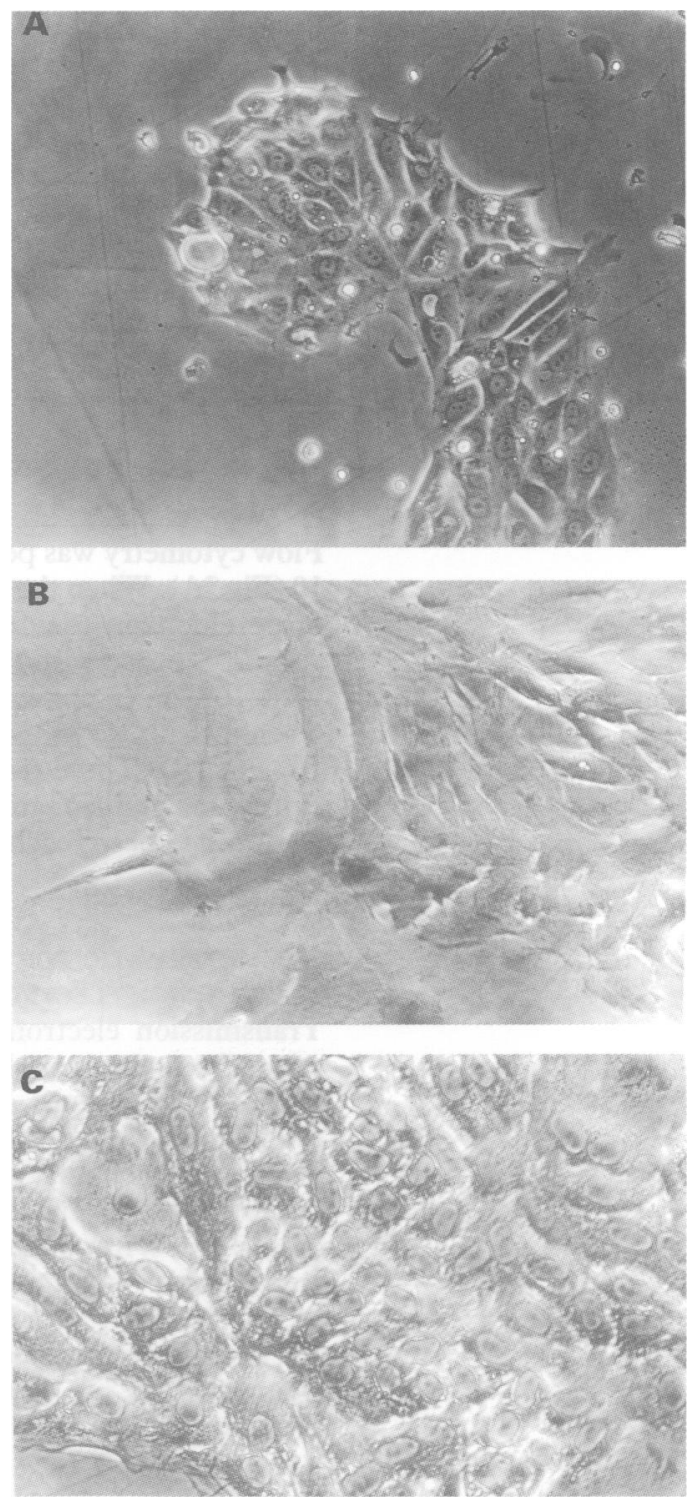

Figure 1: Phase contrast microscopy of bovine epithelial cells in culture. $(A)$ clusters of epithelial cells at day 2 after plating (B) culture appearance at day $6 ;(C)$ monolayer culture at day 10 when the culture is reaching confluency. 


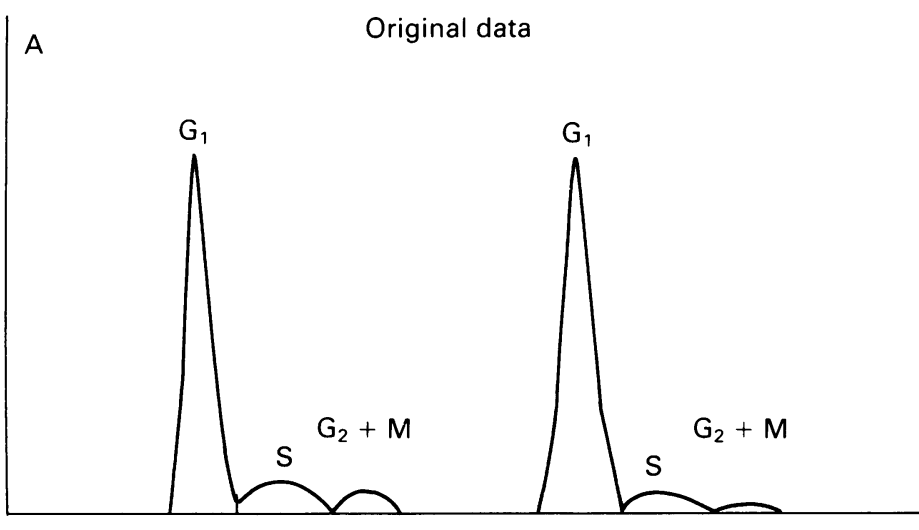

Log phase

Subconfluent phase

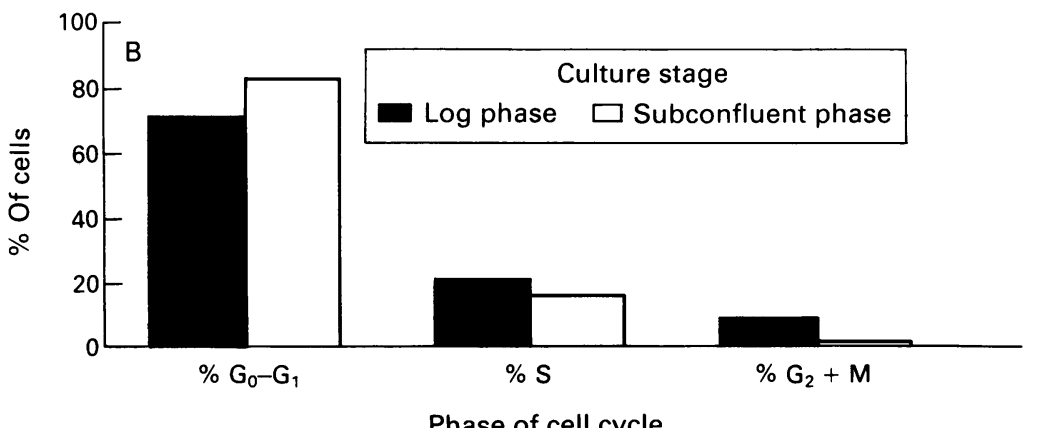

Figure 2: (A) flow cytometric study of gall bladder epithelial cells in culture. Cells were analysed: at the logarithmic phase of development (day 6) and before reaching confluency (subconfluent stage, day 10); (B) percentage of cells at each stage of cell cycle at the logarithmic and subconfluen phase of the cell culture. bladder epithelial cells from the bovine gall bladder. Over the past few years there has been increasing interest in the biological characteristics of biliary and gall bladder epithelial cells in an attempt to enhance our understanding of diseases affecting the biliary tree. Several investigators have attempted to culture biliary cells $s^{19-21}$ but the methods described have tended to be complicated and difficult to apply.

A method of gall bladder tissue culture from the guinea pig gall bladder has been developed ${ }^{22}$ in the hope of providing a direct tool to study the biological and immunological characteristics of these cells. The main disadvantage of tissue culture, however, is the simultaneous growth of other types of cells present in the gall bladder wall, particularly fibroblasts, which may suppress the growth of the epithelial cells; for this reason the method has not been applied widely in the study of epithelial cell function.

A few groups from the United States have reported some success in short term cultures of
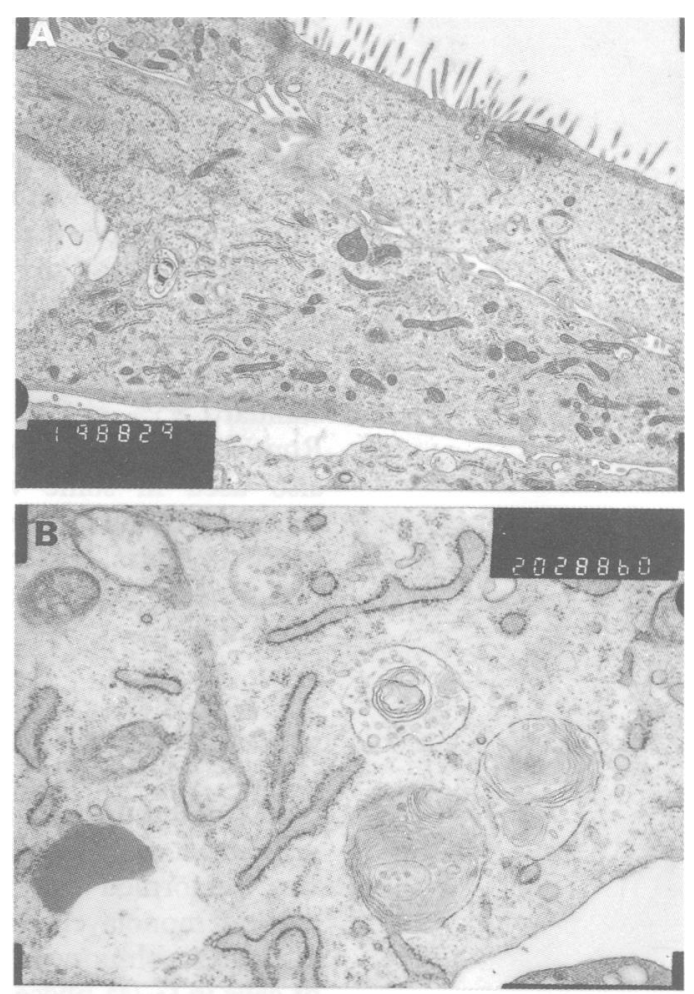

\section{FLOW CYTOMETRY}

Flow cytometry was performed at day 6 and day 10 (Fig 2A). When the cells were in the log phase of development (day 6) there were $21 \%$ of the cells in $S$ phase with $9 \%$ in $G_{2}$ phase compared with $10 \%$ in $S$ phase with $1.55 \%$ in $G_{2}$ phase when the culture was reaching confluency by day 10 (Fig 2B). These results showed that the cell culture maintained satisfactory growth until confluency had been reached.

\section{CHARACTERISATION OF EPITHELIAL CELLS BY} TRANSMISSION ELECTRON MICROSCOPY

Transmission electron microscopy of the cells taken from the monolayer in the subconfluent phase of the culture, showed typical epithelial cells with all the characteristics of the gall bladder epithelium. Cytoplasmic organelles and microvilli on the epithelial cells were prominent (Fig 3A). With higher magnification, dilated endoplasmic reticulum and mucin filled vacuoles were seen (Fig 3B). Focal tight junctions and interdigitating processes between adjacent cells, characteristic of epithelial cells, were also present (Fig 3C).

\section{Discussion}

In this study we report a reliable and reproducible method for harvesting and culturing gall monolaver culture. Cytoplasmic organelles and microvillli on the epithelial cells are prominent (original magnification $\times 6000) ;(B)$ micrograph showing dilated rough endoplasmic reticulum and mucin filled vacuoles (original magnification $\times 20000) ;(C)$ interdigitating processes between adjacent epithelial cells and focal tight junctions (original magnification $\times 20000$ ).
Figure 3: $(A)$ electron micrograph of cells taken from 
either normal human gall bladder cells ${ }^{23}$ or with well differentiated gall bladder adenocarcinoma lines. ${ }^{2+25}$ More recently, Oda et al reported in detail a technique for the harvesting and longterm culture of dog gall bladder epithelial cells. ${ }^{26}$ The dog gall bladder epithelial cells have similarities to bovine cells in a number of biological characteristics (time to reach confluency, division rates, etc) but the method we report in this paper is simpler and quicker. Another significant advantage of our method is the use of bovine tissue, which is easily obtainable and avoids the need for breeding costly experimental animals and the subsequent operation required to retrieve the gall bladder. The availability of bovine tissue allows the use of frequent short term (up to two weeks) primary cultures rather than longterm cultures avoiding problems of cell differentiation, which are likely to occur in longterm cultures. We have also found that the method described for bovine tissue can be applied to human gall bladder epithelial cells and we are currently in the process of culturing and characterising these cells.

The bovine gall bladder model has been studied in our laboratory ${ }^{27}$ and we have shown that there are striking similarities in the composition of bovine and human bile apart from cholesterol concentration, which is five times less in cattle compared with human bile (unpublished data). Bovine bile is lithogenic and the physiology of bovine gall bladder epithelium is similar to the human in terms of electrolyte transport and hydrogen ion secretion. The development of a simple method of gall bladder cell culture from a readily accessible source will facilitate the study of several aspects of gall bladder epithelial cell function and in particular the regulation of ion transport and hydrogen ion secretion, identification and cloning of the several antiport systems and channels operating on the cell membrane, regulation of mucin secretion and prostaglandin metabolism, and will enhance the understanding of the pathophysiological mechanisms of gall bladder disorders.

In conclusion, we present a simple, reliable, and reproducible method of isolation and culturing bovine gall bladder epithelial cells, which remained viable for at least two weeks. This method should be useful for the study of the biological properties of gall bladder mucosal cells both in experimental animals and in humans. J N Plevris has been supported by the William Gibson Fellowship
in Gastroenterology, Faculty of Medicine, University of in Gastroe
This work has been presented at the Autumn Meeting of the British Society of Gastroenterology, Warwick 9-11 September 1992.

1 Reuss L. Ion transport across gallbladder epithelium. Physiol Rev 1989; 69: 503 .

2 Jacyna MR, Ross PE, Bakar MA, Hopwood D, Bouchier IAD Characteristics of cholesterol absorption by human gallbladder: relevance to cholesterolosis. F Clin Pathol 1987; 40 524-9.

3 Lee SP, LaMont JT, Carey MC. Role of gallbladder mucus hypersecretion in the evolution of cholesterol gallstones. f Clin Invest 1981; 67: 1712-23.

4 Reuben A. Biliary proteins. Hepatology 1984; 4: 465-505.

5 Diamond IM. Transport mechanisms in the gallbladder. In: Cook CD, ed. Handbook of physiology: alimentary canal. Washington DC: American Physiological Society, 1968: 2451-82.

6 Heintze K, Petersen KU, Olles P, Saverymuttu SH, Wood JR. Effect of bicarbonate on fluid and electrolyte transport by
the guinea pig gallbladder: a bicarbonate - chloride the guinea pig gallbladder: a bicarbo

7 Rose RC. Absorptive functions of the gallbladder. In: Johnson LR, ed. Physiology of the gastrointestinal tract. Vol 2. New York: Raven Press, 1981: 1021-2.

8 Rege RV, Nahrwold DL, Moore EW. Absorption of biliary calcium from the canine gallbladder; protection against the formation of calcium - containing gallstones. $\mathcal{F} \mathrm{Lab} \mathrm{Clin}$ Med 1987; 110: 381-6.

9 Jacyna MR, Ross PE, Bakar MA, Hopwood D, Bouchier IAD Characteristics of cholesterol absorption by human gallbladder: relevance to cholesterolosis. F Clin Pathol 1987; 40: 524-9.

10 Reuben A. Biliary proteins. Hepatology 1984; 4: 465-505.

11 Lee SP, LaMont JT, Carey MC. Role of gallbladder mucus hypersecretion in the evolution of cholesterol stones. $\mathcal{F}$ Clin Invest 1981; 67: 1712-23.

12 Rege RV, Moore EW. Evidence for $\mathrm{H}+$ secretion by the in vivo canine gallbladder. Gastroenterology 1987; 92: 281-9.

13 Plevris JN, Hayes PC, Harrison DJ, Bouchier IAD. Evidence of hydrogen ion secretion from the human gall bladder in vitro. Gut 1992; 33: 554-9.

14 Gelarden RT, Rose RC. Electrical properties and diffusion potentials in the gall bladder of man, monkey, dog, goose and rabbit. $f$ Membr Biol 1974; 19: 37-54.

15 Dietschy JM. Transport of water in rabbit and guinea pig gallbladder. F Gen Physiol 1964; 48: 1-14.

16 Dietschy JM. Water and solute movement across the wall of the everted rabbit gallbladder. Gastroenterology 1966; 50: the everted

17 Jacyna MR, Ross PE, Hopwood DH, Bouchier IAD. Effects of secretin on sodium ion transport in the human gallof secretin on sodium ion transport in the hum
bladder. Aliment Pharmacol Therap 1989; 3: 293-7.

18 Vindelar LL, Christensen IJ, Nissen NI. A detergent-trypsin method for the preparation of nuclei for flow cytometric DNA analysis. Cytometry 1983; 3: 323-7.

19 Kumar V, Jordan TW. Isolation and culture of biliary epithelial cells from the biliary tract fraction of normal rats. Liver 1986; 6: 369-76.

20 Grant AG, Billing BH. The isolation and characterization of bile ductule cell population from normal and bile duct ligated livers. Br F Exp Pathol 1977; 58: 301-10.

21 Ishii $M$, Vroman B, LaRusso NF. Isolation and morphologic characterization of bile duct epithelial cells from normal rat livers. Gastroenterology 1989; 97: 1236-47.

22 Elhamady MS, Hopwood D, Milne G, Ross P, Bouchier IAD Tissue culture of guinea-pig gallbladder epithelium. Tissue culture of guinea-pir

23 LaRusso NF, Hoerl BJ, Vroman BT, Scott RE. Biological characteristics of cultured human gallbladder epithelial cells [Abstract]. Hepatology 1989; 10: 636 .

24 Morgan RT, Woods IK, Moore EW, McGavron L, Quinn LA, Semple TV. Human gallbladder adenocarcinoma cell line. In Vitro 1981; 503: 17-24.

25 Purdum PP, Hylemon PB, Moore EW. Luminal acidification by cultured human gallbladder epithelium: validation of new experimental model. Gastroenterology 1991; 100: A335.

26 Oda D, Le SP, Hayashi A. Long term culture and partia characterization of dog gallbladder epithelial cells. Lab characterization of dog

27 Plevris JN, Hayes PC, Bouchier IAD. Mechanism of acid secretion in the bovine gallbladder epithelium. Evidence of $\mathrm{Na}^{+} / \mathrm{H}^{+}$exchange. Gut 1990; 31: A1215. 